\title{
Peningkatan Sikap Sosial Positif melalui Outing Class Permainan Tradisional Interaktif
}

\author{
Galih Yansaputra ${ }^{1}$, Rintis Rizkia Pangestika ${ }^{2}$ \\ ${ }^{1}$ Universitas Muhammadiyah Purworejo \\ ${ }^{2}$ Universitas Muhammadiyah Purworejo \\ Email :intermilane90@gmail.com¹, rintisrizkia@gmail.com²
}

\begin{abstract}
ABSTRAK
Tujuan dari pengabdian kepada masyarakat ini meliputi mengenalkan kebudayaan berupa permainan tradisional yang interaktif kepada siswa sekolah dasar yang dimana di era global ini banyak dari mereka yang belum tahu akan manfaat dari permainan ini, menumbuhkan sikap sosial yang positif antar teman, menciptakan pembelajaran yang menyenangkan, menambah wawasan kepada siswa tentang kebudayaan yang ada di sekitar, dan melestarikan kebudayaan. Target khusus yang ingin dicapai dari kegiatan pendampingan pengabdian kepada masyarakat yang meliputi memberikan pengetahuan baru tentang permainan tradisional dan melestarikan kebudayaan. Metode yang akan dipakai dalam mencapai tujuan kegiatan pendampingan pengabdian kepada masyarakat yaitu dengan memberikan berbagai macam outing class melalui permainan tradisional yang interaktif. Hasilnya menunjukkan bahwa melalui permainan tradisional interaktif ini, antar siswa sudah dapat menunjukkan sikap sosial yang positif, siswa merasa senang dalam pembelajaran, siswa menjadi tahu tentang kebudayaan Indonesia yang berupa permainan tradisional.
\end{abstract}

Kata Kunci: permainan tradisional, sikap sosial, outing class

\section{Increasing Positive Social Attitudes through Traditional Interactive Game Outing Classes}

\begin{abstract}
The purpose of community service includes introducing culture in the form of interactive traditional games to elementary school students, where in this global era many of them do not know the benefits of the game, foster positive social attitudes among friends, create fun learning, add insight into students about the culture around them, and preserve culture. Specific targets to be achieved from community service assistance activities include providing new knowledge about traditional games and preserving culture. The method that will be used in achieving the objectives of community service assistance activities is by providing various outing classes through interactive traditional games. The results show that through this interactive traditional game, between students can already show positive social attitudes, students feel happy in learning, students come to know about Indonesian culture in the form of traditional games.
\end{abstract}

Keywords: traditional game, social attitude, outing class

\section{PENDAHULUAN}

Pada pembelajaran idealnya mencakup beberapa kompetensi yang diajarkan pada setiap pertemuannya.
Tentu banyak sekali persiapan yang perlu disiapkan untuk membuat sebuah pembelajaran yang ideal dan lebih bermakna. Karena jika 
penyampaian pengetahuan dalam proses pembelajaran kurang tepat maka akan berdampak pada kegiatan pembelajaran yang ditempuh oleh para siswa di kelas menjadi kurang bermakna. Banyak dari mereka yang jenuh dengan kegiatan yang hanya berada di dalam suatu ruangan maupun kelas yang telah disediakan oleh pemerintah maupun pihak pengelola pendidikan. Maka, proses kegiatan pembelajaran yang tidak inovatif tersebut akan menimbulkan rasa jenuh yang dirasakan oleh siswa. Hal ini akan mengakibatkan kurang minatnya siswa dalam mengikuti proses pendidikan dan menghambat penyampaian ilmu pengetahuan pendidikan.

Oleh karena hal itu, diperlukan strategi khusus untuk menghadapi permasalahan tersebut. Kendala yang sering terjadi pada tenaga pendidik terutama guru SD anatara lain mengenai karakter yang berbedabeda pada siswa yang diajar. Selain itu yang sering dijumpai oleh para tenaga pendidik di lapanganya itu cepat bosannya mereka di dalam kelas sehingga banyak dari mereka yang tidak paham akan materi pembelajaran yang telah diberikan oleh gurunya. Dengan adanya pembelajaran yang menekankan pada outing class akan menimbulkan suasana yang jauh berbeda dengan apa yang ada di dalam kelas membuat anak banyak yang antusias untuk mengikuti pembelajaran apalagi ditambahkan dengan kolaborasi permainan tradisional yang pada dasarnya merupakan kegiatan yang sering mereka lakukan di rumah. Penggunaan metode ini memang banyak manfaat jikalau terjadwal dan intens. Karena dengan metode ini siswa dapat menumbuhkan sikap sosial positif dengan temannya.

Kegiatan outing class melalui permainan tradisional ini ditujukan bagi siswa MI Muhammadiyah Krendetan Purworejo supaya dapat mengambil banyak manfaat dari permainan tradisional ini. Melalui kegiatan ini dapat diperoleh manfaatya itu memudahkan siswa untuk menambah kemampuan lebih dekat secara psikologis terhadap teman siswa yang lain, sehingga dengan kedekatan ini anak akan lebih mudah dalam menangkap dan memahami ilmu pengetahuan yang akan disampaikan. Karena kegiatan belajar yaitu ikut berpartisipasi dalam permainan tradisional secara interaktif maka siswa tidak kaku dalam mengikuti pembelajaran outing class. Pada pengabdian ini, permainan tradisional yang disampaikan yaitu permainan tradisional yang mengandung unsur interaktif.

\section{METODE PENELITIAN}

Metode pelaksanaan kegiatan ini adalah pelatihan dengan perpaduan teori dan praktik serta diskusi. Kegiatan pelatihan ini diberikan kepada guru di MI Muhammadiyah Krendetan Purworejo.

Pelaksana pendampingan ini dibantu oleh 15 mahasiswa PGSD sebagai pelaksana lapangan dalam pendampingan yang diketuai oleh 2 dosen. Peserta dalam pendampingan 
ini adalah guru kelas dan siswa kelas I, II,dan III yang dijadikan objek dalam pendampingan.

Langkah-langkah kegiatan pengabdian yang akan dilakukan yaitu yang pertama, melakukan briefing terlebih dahulu dengan guru kelas yang mengampu kelas yang akan dita dampingi. Kedua, mengkondisikan siswa terlebih dahulu dengan melakukan ice breaking. Ketiga, mengenalkan satu persatu permainan tradisional antara lain: congklak, surga neraka, ular naga, boy-boyan, domikado, dan permainan yang lainnya. Kegiatan yang kedua yaitu sharing yang berkaitan dengan materi IPS dan matematika. Kegiatan permainan tradisional tersebut bertujuan untuk menumbuhkan sikap sosial, motivasi dalam belajar, dan peduli terhadap budaya Indonesia.

Kegiatan di atas merupakan rangkaian kegiatan pelaksanaan pendampingan pengabdian kepada masyarakat yang dilakukan di MI Muhammadiyah Krendetan Purworejo dengan bantuan dari mahasiswa PGSD angkatan 2017 untuk terlibat dalam mengisi kegiatan tersebut.

\section{HASIL DAN PEMBAHASAN}

Pada tanggal 11 Desember 2018, tim pengabdian melakukan perencanaan dengan para guru (peserta pengabdian). Kegiatan ini juga dibantu oleh beberapa mahasiswa PGSD. Kegiatan yang dilakukan antara lain: Pertama, tim pengabdian memberikan beberapa konsep materi tentang permainan tradisional yang interaktif. Kedua, peserta pengabdian mencoba untuk menganalisis materimateri yang akan dilaksanakan dengan menerapkan permainan tradisional yang interaktif. Ketiga, peserta pengabdian mencoba membuat desain pembelajarannya.

Pada hari berikutnya, para peserta pengabdian melaksanakan desain pembelajaran yang telah dibuat dengan didampingi oleh mahasiswa PGSD yaitu melakukan outing class permainan tradisonal interaktif. Hasil kegiatan pengabdian di MI Muhammadiyah Krendetan ini adalah sebagai berikut:

1. Para guru MI Muhammadiyah Krendetan yang berjumah 10 orang telah mampu membuat desain pembelajaran permainan tradisional yang dikaitkan dengan materi-materi dalam pembelajaran.

2. Para guru dapat menerapkan desain pembelajaran permainan tradisional dengan baik.

3. Melalui kegiatan pengabdian ini dapat mengenalkan kebudayaan Indonesia.

4. Sikap sosial positif siswa terhadap materi pembelajaran maupun terhadap proses belajar itu sendiri dapat ditingkatkan. Hal ini ditunjukkan dari kerja sama, sikap toleransi, kreativitas, komunikatf, peduli sosial, peduli lingkungan dan solidaritas yang dilakukan oleh siswa ketika memainkan permainan tradisional.

5. Proses belajar mengajar menjadi lebih menarik, dengan adanya permainan tradisional. Hal ini ditunjukkan dari semangat siswa dalam mengikuti kegiatan outing class permainan tradisional interaktif.

Berdasarkan hasil pengabdian 
kepada masyarakat di atas maka dapat di uraikan bahwa dengan adanya kegiatan ini maka dapat mengenalkan kembali kebudayaan Indonesia melalui permainan tradisional. Karena permainan anak usia sekolah dasar era sekarang mayoritas sudah beralih ke permainan modern seperti games yang ada di gadget. Kemudian, melalui kegiatan ini sikap sosial adalah kesadaran individu yang menentukan perbuatan nyata dan berulang-ulang terhadap objek sosial. Sikap sosial dinyatakan tidak oleh seorang tetapi diperhatikan oleh orang-orang sekelompoknya. Objeknya adalah objek sosial (banyak orang dalam kelompok) dan dinyatakan berulangulang (Ahmadi, 2007: 152). Oleh karena itu, berdasarkan hasil yang diperoleh yaitu sikap sosial yang terjadi meningkat. Peningkatan ini dilihat melalui kegiatan kelompok ketika sedang memainkan permainan tradisional interaktif. Dimana aktivitas sosial yang terjadi antara lain :

1. Toleransi ialah suatu sikap saling menghormati dan menghargai antar kelompok atau antar individu dalam masyarakat atau dalam lingkup lainnya.

2. Kreatif yakni suatu proses pemikiran yang membantu mencetuskan berbagai gagasan yang merupakan sifat manusia yang dibentuk dariproses pengalaman.

3. Bersahabat/ komunikatif adalah orang yang mudah bergaul dengan orang lain biasanya selain mampu menyampaikan, juga mampu mendengarkan oleh orang lain untuk kemudian direspon dengan cara yang tepat.

4. Peduli lingkungan yaitu program pengelolaan lingkungan

secara benardan bermanfaat sehingga dapat dinikmati secara terus menerus tanpa merusak keadannya, turut menjaga dan melestarikan sehingga ada manfaat yang berkesinambungan.

5. Soldaritas adalah rasa kebersamaan, rasa kesatuan kepentingan, rasa simpati, sebagai salah satu anggota dari kelas yang sama.

Pembelajaran di luar kelas atau outing class yaitu suatu kegiatan yang melibatkanalam secaralangsunguntuk di jadikan sumber belajar (Vera, 2012: 17). Kemudian, permainan tradisional merupakan permainan alternatif yang kaya dengan nilai budaya (culture), dan bahkan mungkin saat ini sudah hampir punah jika tidak dipelihara dan dikembangkan. Hal tersebut selaras dengan pernyataan dari Andriani (2012) dalam Pangestika (2019: 304) bahwa permainan tradisional berasal dari kata permainan dan tradisional. Permainan berarti sesuatu atau barang yang dipakai untuk bermain, sedangkan tradisional yaitu perilaku, cara berpikir, dan berbuat sesuatu yang selalu berpedoman pada norma dan adat istiadat yang ada secara turuntemurun. Sementara, Afrianti (2014 : 10) mengemukakan bahwa permainan tradisional dapat menjadi alternatif media untuk mengembangkan kompetensi sosial dan emosi. Terdapat berbagai pilihan permainan yang dapat dimodifikasi sesuai kondisi anak. Nilai-nilai yang terkandung dalam permainan tradisional selain menyenangkan juga mengembangkan sikap membantu teman, mentaati 
peraturan, menunjukkan rasa percaya diri, kooperatif, tidak menyerah dan mengembangkan jiwa sportivitas. Melalui permainan tradisional yang interaktif ini maka akan terjadi interaksi sosial antar siswa. Dimana interaksi sosial ialah hubungan antara individu satu dengan yang lain, individu satu dapat mempengaruhi individu yang lain atau sebaliknya, jadi terdapat adanya hubungan yang saling timbal balik. Hubungan tersebut dapat antara individu dengan individu, individu dengan kelompok dengan kelompok (Fitriastuti, 2013: 183188). Pembelajaran di luar kelas di harapkan mendekatkan anak dengan alam dan lebih mendekatkan anak dengan alam. Tidak hanya itu, outing class permainan tradisional interaktif juga dapat membuat daya kreativitas anak semakin meningkat, anak lebih mandiri, kreatif, inovatif dan mendekatkan anak dengan teman sekolahnya.

Kegiatan outing class permainan tradisional interaktif senada dengan yang dikemukakan oleh Sawyer (Bergen, 2001) yaitu bahwa, "... rather than following a script, much of preschool children's pretend play involved improvisational exchanges. He also found that these strategies were more succsessfull when they were implicity included in the play scenario rather than when children stopped the play to make explicite suggestion." Permainan tradisional dapat diyakini akan memberikan dampak yang lebih baik bagi pengembangan potensi anak, jika permainan modern lebih mengutamakan individualisasi, maka permainan tradisional lebih memberikan kesempatan kepada anak untuk bersosialisasi dan berkerjasama dalam kelompok. Hal tersebut juga diperkuat oleh Bordova \& Leong (2003) bahwa, “... now a days young children spend less time playing with their peers and more time playing alone, graduating frorm educational toys to video and computer game."

Maka dari itu, kegiatan pembelajaran tersebut dapat dikatakan pembelajaran yang menyenangkan karena kegiatan bermain adalah kesenangan para anak-anak (Rindani, 2017: 21). Melalui bermain anak tidak akan merasakan jenuh dengan lingkungan ataupun hal lain yang penuh tuntutan seperti pembelajaran di kelas. Jadi seorang guru dapat menerapkan metode bermain sambil belajar. Anak akan menjadi lebih aktif dalam pembelajaran. Kemudian, melalui aktivitas bermain anak- anak belajar tentang interaksi sosial dengan teman sebayanya, dimana anak-anak belajar memahami, beradaptasi dalam kelompok dan berkomunikasi dengan orang lain (Latifah dan Sagala, 2015: 115).

Hal ini didukung oleh penelitian yang dilakukan oleh Mahardika (2014: 266) yang mana melalui penerapan permainan tradisonal, sikap-sikap sosial positif anak dapat meningkat. Penelitian yang senada juga dihasilkan oleh Erdiana (2016: 15) bahwa permainan tradisional gobak sodor berpengaruh terhadap perkembangan sikap kooperatif anak.

Selain itu, dengan menerapkan permainan tradisional sama halnya 
melestarikan kebudayaan bangsa Indonesia. Karena nilai-nilai budaya yang terkandung dalam permainan tradisional menurut Sukirman Dharmamulya (Ismail, 2006: 106), antara lain: melatih sikap mandiri; berani mengambil keputusan; penuh tanggung jawab; jujur; sikap dikontrol oleh lawan; kerjasama; saling membantu dan saling menjaga; membela kepentingan kelompok; berjiwa demokrasi; patuh terhadap peraturan; penuh perhitungan; ketepatan berpikir dan bertindak; tidak cengeng; berani; bertindak sopan; dan bertindak luwes.

Kegiatan pengabdian kepada masyarakatyangberupapendampingan ini sangat sesuai dengan kebutuhan para guru di MI Muhammadiyah Krendetan Purworejo. Karena para guru dituntut untuk memiliki kemampuan mengajar yang inovatif dan kreatif. Dengan demikian dapat dikatakan bahwa kegiatan pengabdian kepada masyarakat ini telah mencapai hasil yang diharapkan.

\section{SIMPULAN}

Berdasarkan pemaparan hasil pengabdian di atas, maka dapat disimpulkan bahwa melalui permainan tradisional interaktif ini, antar siswa sudah dapat menunjukkan sikap sosial yang positif, siswa merasa senang dalam pembelajaran, siswa menjadi tahu tentang kebudayaan Indonesia yang berupa permainan tradisional.

\section{DAFTAR PUSTAKA}

Afrianti, Nurul. 2014. Permainan Tradisional, Alternatif Media Pengembangan Kompetensi
Sosial-Emosi Anak Usia Dini. Jurnal Cakrawala Dini. Vol. 5 No. 1. Hal. 1-12.

Bergen, Doris. 2001. Pretend Play and Young Children's Development. Journal ERIC. Digest. ED458045.

Bordova, Elena\&Leong, J. Deborah. 2003. Do Play and Foundational Skills Need toCompete for The Teacher's attention in an early Childhood Classroom. Journal ERIC Digest.

Erdiana, Lita. 2016. Pengaruh Permainan Tradisional Gobak Sodor Terhadap Perkembangan Motorik Kasar Dan Sikap Kooperatif Anak TK Kelompok B Di Kecamatan Sidoarjo. Jurnal Pedagogi. Vol. 2 No. 3. Hal. 9-17.

Fitriastuti, Febriani. 2013. Pengaruh Interaksi Sosial Dalam Keluarga dan Minat Belajar Siswa Terhadap Prestasi Belajar Siswa. Jurnal Oikonomia. Vol.2. hal 183-188.

Ismail, Andang. 2006. Education Games: Menjadi Cerdas dan Ceria dengan Permainan Edukatif. Yogyakarta: Pilar Media.

Latifah, U \& Sagala, A.C.D. 2015. Upaya Meningkatkan Interaksi Sosial Melalui Permainan Tradisional Jamuran Pada Anakkelompok B TK Kuncup Sari Semarang Tahun Pelajaran 2014/2015. Jurnal Penelitian PAUDIA. Hal. 112-132.

Mahardika, E.K. 2014. Peningkatan Perilaku Sosial Anak melalui Permainan Tradisional Jawa. Jurnal Pendidikan Anak Usia Dini. Vol. 8 Edisi 2. Hal. 257268.

Pangestika, Rintis Rizkia. 2019. Permainan Tradisional Edukatif Sebagai Metode Pembelajaran Matematika Siswa Sekolah Dasar. Prosiding Seminar 
Nasional Pendidikan Dasar. Prodi PGSD Universitas Muhammadiyah Purworejo.

Rindani, Fenti. 2017. Pengembangan Sikap Sosial Dengan Permainan Tradisional Bakiak Pada Anak Kelas B 1 Ra Ma'arif Pulutan Salatiga Tahun Pelajaran 2016/2017. Skrispi : IAIN Salatiga.

Vera, Adelia. 2012. Metode Mengajar Anak di Luar Kelas (Outdoor study).: Jogyakarta. DIVA press. 